\title{
KILDESMITTE. MIKKEL BOLT OG AVANTGARDENS IDEALISME
}

\author{
ANMELDELSE AF \\ Mikkel Bolt. Avantgardens selvmord, København, 2010 (Forlaget 28/6)
}

Et av Sigmund Freuds hovedpoenger i Totem og tabu (1913) er at læring betinger gjentagelse. Ifølge Freud er barndommen en slags fortfilm-versjon av den menneskelige evolusjon: I løpet av sine første leveår er barnet nødt til å rekapitulere homo sapiens’ nærmere 200000 år lange tilblivelseshistorie. Ontogenesen er å betrakte som en gjentagelse av fylogenesen; individets coming-of-age er en speiling av artens utvikling gjennom flerfoldige stadier.

Freud baserte sin evolusjonsteori på biologiske antagelser som for lengst er falsifisert. På slutten av 1800-tallet forestilte man seg at det menneskelige embryo gjennomgikk en "fiskefase" med utvikling av gjelleåpninger, deretter en "reptilfase" med utvikling av en lang hale, etc., etc. For dagens lesere er dette science fiction i ordets rette forstand. En ikke-essensialistisk variant av det samme prinsippet ("ontogenesen rekapitulerer fylogenesen”) lever likevel videre i samfunnsvitenskapene: Vår tids sosiologer forutsetter at det fins en unik "arv" innskrevet i alle samfunnsmessige delområder; en kumulativ historie som aktørene må innforlives med, praktisk såvel som teoretisk, for å vinne inntreden i feltet. "Hele feltets historie," skriver Bourdieu, "er innkapslet $\mathrm{i}$ alle dets tilstander, og for å leve opp til feltets objektive krav - som produsent, men også som konsument - må man praktisk eller teoretisk beherske denne historien og det rom av muligheter hvor den lever videre." (Bourdieu, Konstens regler: $350-51$, min oversettelse fra svensk).

Paradoksalt nok er det ingen som tynges mer av disse kravene enn avantgarden, som uunngåelig er definert av det de søker å overskride. Feltets historie er irreversibel; det går ikke an å "nullstille" delområdets nomos, dets grunnleggende lov. Skal du spille mot, må du også spille med, i den forstand at du må kjenne sjangerens spesifikke teorier, metoder og teknikker til fingerspissene. "All in the game yo, all in the game," som Omar Little ville sagt det. Men nettopp fordi avantgardeposisjonen forutsetter en innfiltring i feltets disciplinary matrix (Kuhn), slår mange slike prosjekter over i konservatisme: Når man først har innsett at motsetningen forener - at uoverensstemmelsen ikke er en trussel, men en garant for feltets relative autonomi - ja, så er det nærliggende å tenke at det strengt tatt ikke spiller noen rolle 
hvilken posisjon man inntar; dissidenten er ikke mindre viktig for institusjonens overlevelse enn kulturfyrsten.

Mikkel Bolts studier av det 20. århundrets avantgardehistorie har heldigvis ikke gjort ham konservativ. Avantgardens selvmord, Bolts nyeste bok, inneholder et sluttkapittel hvor forskeren framstår som den fødte folketribun - med friske synspunkter på bl.a. Attac, Hugo Chavez og USAs svulmende utenlandsgjeld. Slike rollebytter står det respekt av; flere akademikere skulle våge spranget fra det deskriptive til det preskriptive.

Til gjengjeld opplever jeg at bokas øvrige kapitler - som stort sett er et konsentrat av Bolts doktorgradsavhandling, Den sidste avantgarde. Situationistisk Internationale binsides kunst og politik fra 2004, ispedd noen betraktninger om Georges Bataille - i for høy grad er farget av avantgardens selvforståelse. Ikke så å forstå at Bolt snakker sine studieobjekter etter munnen; snarere har vi å gjøre med en stilltiende overenskomst om avantgardediskursens nødvendighet, en solidarisk tiltro til at "det som står på spill” i avantgardens sosiale mikrokosmos, virkelig er verdt å diskutere. Ironisk nok advarer Bolt mot en sådan "kildesmitte" - som en avisredaktør ville kalt det - i bokas åpningskapittel: "Avantgarden er en særlig gestus, der tager form af et påbud. Avantgarden kræver at blive behandlet på en særlig måde.” (21). Debord innprentet dette poenget overfor kultursosiologen Robert Estivals allerede i 1963: Avantgarden kan ikke forstås "utenfra". Den interne selvforståelse = den eksterne forståelse. Ønsker man å bli klok på avantgarden, må man akseptere og internalisere avantgardens teori. Ethvert forsøk på å applisere eksterne analyseverktøy er ifølge Debord "et absurd foretagende".

Debords holdning er på ingen måte ekstrem. Begeistringen for "inntrengere” er ikke synderlig større i andre sosiale felter; det er bare sjelden at eksklusjonsprinsippene blir proklamert så høytlytt. Alminnelig prosedyre er at aktører som ikke er innforstått med spillets regler, brutalt avfeies som "naive" eller "uvitende". Slik pågår det en kontinuerlig avgrensning av rommet for legitim diskusjon. Mitt ankepunkt mot Bolt er nettopp at han i så liten grad utfordrer dette rommet for "mulige spørsmål og svar": Ettersom Bolt ikke tillater seg å være "naiv" i møte med avantgarden, forspiller han også muligheten til å analysere feltet fra en uventet posisjon.

Hva kunne så en "naiv" analyse av avantgarden bestå i? En god begynnelse ville være å utfordre aktørenes eksepsjonalistiske selvforståelse. Guy Debord \& co. trakk riktignok linjer tilbake til dada, surrealismen og en del marxistiske teoretikere, men bare i en slik grad at valgslektskapene ikke utfordret the bottom line: Ideen om at Situasjonistisk Internasjonale utgjorde "menneskehedens mest avancerede bevidsthed" (Bolt, Den sidste avantgarde: 73). Denne forestillingen var dobbelt feilaktig: For det første er ikke SIs tankegods unikt, verken i for- eller ettertid. For det andre førte eksepsjonalismen til et ideologisk renhetshysteri - en notorisk paranoia overfor alle krefter som kunne tenkes å forurense bevegelsens "avancerede bevidsthed". Men som Terry Eagleton har påpekt, er ikke hovedproblemet med avantgardens kritikk at den står i fare for å bli "kooptert" av borgerskapet; snarere at den har vært sauset sammen med borgerlig ideologi allerede fra begynnelsen av: 
"From Marx to Marcuse, Plekhanov to Della Volpe, "Marxist aesthetics" has been for the most part an ambiguous amalgam of idealism and materialism; and that "impurity", not least in its post-Bolshevik developments, has a historical ground. The vulnerability of Western Marxism to idealist deformations lies above all in its relative separation from mass revolutionary practice; and the fate of most "Marxist aesthetics" has been to reproduce this condition at a specific level." (Eagleton: 82).

Når Eagleton skriver "idealisme”, tenker han selvsagt på Kant, men framfor alt på Kants etterfølgere - Hegel, Schelling og Schiller, som utviklet sine tankesystemer i kjølvannet av den franske revolusjonen. Ved overgangen til 1800-tallet hadde adel og borgerskap innledet sin siste, store tvekamp, og begge søkte fortvilet å alliere seg med kunstnerne. I takt med at borgerskapet demonterte den ene føydale institusjonen etter den andre, oppsto behovet for en ny universalistisk overbygning. Oppdraget ble outsourcet til kunsten. Det moralske og politiske fellesskapet som ikke lot seg realisere på "det frie marked”, ble i stedet projisert i stedet inn i kunstverket. Etikk = estetikk: Liksom de fremadstormende industriherrene på markedet, gjorde kunstnerne i sine verker "nøyaktig som de vil[le]", og resultatet var likevel "til felleskapets beste".

Det gamle aristokratiet appellerte til kunstnerne av litt andre grunner. For dem representerte kunsten et vern mot det borgerlige samfunnets arbeidsdeling og differensiering. "Aldri har individene vært mer spredt og avsondret fra hverandre enn i dag," sukket Goethe tidstypisk. Det er denne smerten kunsten ble satt til å lindre. Lengst gikk Schelling, som i Älteste Systemprogramm des deutschen Idealismus (1796/97) tok til orde for at en "ny mytologi", kunsten, skulle forene atskilte samfunnssfærer "som søsken”. ${ }^{1}$ Kunsten var altså tiltenkt den rolle religionen spilte i middelalderen, som forsoningsparadigme og ivaretager av de samfunnsmessige "restbehov" (Habermas) - behov som ikke lot seg tilfredsstille innenfor rammene av det kapitalistiske samfunn.

Det mest påfallende ved Batailles "verdslige mystikk" i Acéphale-perioden (1936-39) er ikke egentlig hans affinitet til Hitler, som gjorde at han kom på kant med André Breton, men hvor konsekvent han bedriver avskrift av nettopp den tyske idealismens program. I likhet med Schelling beklager Bataille det moderne samfunns atskillelse av kunst, politikk og vitenskap; Acéphales målsetning er simpelthen å gjenskape den "den tapte totalitet". Bindemiddelet er en "ny religion" men en ateistisk sådan. Batailles studier av fascismen har overbevist ham om at politikken må tillate seg å operere på et "mytologisk nivå”, hvor affekter, eksaltasjon og irrasjonelle impulser får fritt spillerom. Hitlers suksess skyldes at han våget å slippe løs samfunnets heterogene krefter. I Batailles øyne må den antifascistiske fronten betjene seg av de samme våpnene, men vende dem mot fascismen selv.

1 De lærde strides om hvem som egentlig skrev "Systemprogrammet”; også G.W.F. Hegel og Friedrich Hölderlin er lansert som forfattere. Innholdet ligger imidlertid svært nær Schellings System des transcendentalen Idealismus (1800) og Philosophie der Kunst (1802/03). 
Liksom Bataille offisielt er antifascist, men inspirert av fascismen som "organisk bevegelse”, er Schelling antiabsolutist, men full av respekt for den stabilitet, sammenheng og "helhet" det opplyste eneveldet tross alt garanterte. Hans systemprogram er en underlig miks av modernisering og restaurasjon, opplysning og motopplysning - oppsummert i oksymoronet "fornuftens mytologi":

"Før vi gjør ideene estetiske, dvs. mytologiske, har de ingen interesse for folket, og omvendt, før mytologien er fornuftig, må filosofen skamme seg over den. Så må endelig de opplyste og de uopplyste rekke hverandre hånden, mytologien må bli filosofisk og folket fornuftig, og filosofien må bli mytologisk for å gjøre filosofene sanselige. Da råder evig enhet blant oss." (Schelling, Den tyske idealismens eldste systemprogram: 106).

Fra Kant har Schelling arvet ideen om kunsten som særegent kompetanseområde. Kunstverket forsoner subjekt og objekt, frihet og nødvendighet, erkjennelse og handling - og det skjer, spektakulært nok, uten hjelp av forstanden. Men i motsetning til Kant er ikke Schelling fornøyd med å etablere kunsten som en autonom sfære ved siden av moral og vitenskap. Når kunsten først er identifisert som åstedet for "åpenbaringen av det Absolutte”, gir det seg nesten selv at feltet må innrømmes forrang over de øvrige delområder; ja, at "kunsten er forbildet for vitenskapen" (Schelling, System des transcendentalen Idealismus: 22-23, min oversettelse), og at filosofien må strebe etter en "tilbakekomst ... til poesien" (Hegel: 235, min oversettelse).

Fra Schelling går det en linje over de tyske ungromantikerne i Athenaeum Novalis og brødrene Schlegel - til Bataille og hans losjebrødre. I en viss forstand hører også situasjonistene hjemme i dette selskapet: Selv om SIs uttalte mål var å oppheve kunsten i revolusjonær praksis, er programmet motsigelsesfullt. Bruddet er uunngåelig også en forsoningsgest. Parolene om "oppløsning" og "overskridelse" skygger for det faktum at situasjonistene vel så gjerne taler ømt om "mytens fellesskap" og "samfunnets gamle fellesspråk" (Debord: 135). Fienden er ikke bare kapitalismen, men selve "atskillelseskulturen" (ibid.). Bolt berørte så vidt dette problemet i sin doktoravhandling:

"Kritiken af skuespilsamfundets billedmæssige forening af den kapitalistisk opsplittede verden blev gennomført med baggrund i en forestilling om, at verden tidligere havde "hængt sammen", været en helhed. Ifølge situationisterne havde det primitive liv før kapitalismen været baseret på et fællesskab, som nu var borte.” (Bolt, Den sidste avantgarde: 49).

I Avantgardens selvmord blir ikke situasjonistenes enhetslengsel nevnt med ett ord. Når "selvmordet" skal forklares, blir vi i stedet fortalt - med en karakteristisk diffus formulering - at avantgardisten "går i opløsning i jagten på sig selv" (23). Jeg skulle gjerne sett at Bolt trasket videre der han tverrsnudde i doktoravhandlingen, og heller spurte seg selv (og oss andre): Har dedifferensiering noensinne vært et 
radikalt krav - på Jena-campusen i 1800, ved Seinens venstre bredd i 1958, eller for den saks skyld i Norge og Danmark på 1970-tallet, da unge maoister høylytt slo til lyd for "partilitteratur" og "folkekunst"?

Mitt svar er nei: Antikapitalisme betinger ikke en kritikk av den samfunnsmessige spesialisering. I en tid hvor bedriftsøkonomiens logikk siver inn i stadig flere samfunnssfærer, herunder kunstens og vitenskapens felter, er dette poenget kanskje viktigere enn noensinne. Og det er heller ikke riktig, som så mange kulturdebattanter antar, at det eksisterer en direkte motsetning mellom autonomi og politisk effektivitet: Kunstnerens distanse til det politiske feltet er tvert imot selve forutsetningen for hennes "innblanding" i den offentlige samtalen. Derfor skulle alle radikale kunstnere, som Bourdieu har påpekt, søke å “... øke sin autonomi (og derigjennom blant annet sin kritiske frihet overfor makthaverne)" (Bourdieu, Konstens regler 475, min kursivering og oversettelse fra svensk). At feltets cover charge dermed stiger, må heller bøtes på ved at man samtidig "allmenngjør betingelsene for tilgang til det universelle” (Bourdieu, Om fjernsynet: 94), dvs. gjennom en politikk som fremmer sosial utjevning.

Den idealistiske estetikken rommer likevel et moment av sannhet. Marx' analyse av religionen har gyldighet også for det autonome kunstverket: Det er på én gang "uttrykk for den virkelige elendigheten og en protest mot den virkelige elendigheten". At den borgerlige moral forvises til en ideell sfære, bidrar til å "lette trykket" i den kapitalistiske hverdagslivet, men er samtidig et vitnesbyrd om mangelen på moral i samfunnet her og nå. Det siste åpner for en radikal kritikk av kapitalismens tilkortkommenheter. Men hvordan skal dette potensialet realiseres? Avantgardens institusjonskritikk har så langt virket mot sin hensikt. Situasjonistenes "industrielle maleri" var kanskje tiltenkt en rolle som nedbrytningsgestus, men har snarere tjent til å utvide repertoaret av gjenstander det er mulig å få konsekrert som "kunst". Kunstpublikummet er i sin tur blitt pent nødt til å oppgradere sine distingverende evner, og avstanden mellom kunsten og "massene" har - helt motsatt hensikten bare økt.

Levende organismer vokser ved celledeling. Spaltingen, eller bruddet, later også til å være kunstinstitusjonens vekstprinsipp: Selv rene opphevelsesforsøk - som avantgardens bestrebelser på å omsette kunsten i livspraksis - fører bare til ytterligere autonomisering. I så måte står avantgarden i et paradoksalt skjebnefellesskap med de tyske idealistene: Heller ikke Schelling ønsket seg et avsondret kunstfelt. Hans mål var forsoning, ikke atskillelse. Historiens ironi er at Schellings tenkning om kunst og samfunn kom til å danne det normative utgangspunkt for institusjonen kunst, i vår tid videreført som universitetsformidlet autonomiestetikk. For kunstens del er det altså sant, som Bruno Latour hevder, at "vi aldri har vært moderne": Moderniseringen av feltet er i høy grad drevet fram av antimoderne tankegods.

Situasjonistenes idealistiske tilbøyeligheter kommer også til uttrykk i deres helt spesielle versjon av den marxistiske ideologikritikken. For Marx gjaldt det å skjelne 
mellom sant og usant $i$ ideologien; ikke å stille egen "sannhet" i skarp kontrast til ideologiens generelle "usannhet". Men for situasjonistene er dette skillet mellom "ideologikonsumenter" og "ideologikritikere" et poeng i seg selv. De betrakter sin egen krets som det siste bolverk mot skuespillsamfunnet; en hard kjerne av unntaksmennesker hvis "mentale reserve" for all del må vernes mot ideologisk kontaminering. Heller enn å framstille fysiske kunstverker, som altfor enkelt kan assimileres i systemets hegemoniske pluralisme, velger de derfor å gå under jorda og meddele seg gjennom politiske manifester.

I våre dager framstår en sådan ideologiforståelse merkelig utdatert. Ingen tror lenger at revolusjonen kan innventes som en automatisk virkning av massenes "bevisstgjøring”. Som Peter Sloterdijk påpeker i Kritik der zynischen Vernunft (1983), er vår tidsalder preget av en "opplyst falsk bevissthet": Den moderne borger handler mot bedre vitende; hun vet hva hun gjør, men hun gjør det likevel. Dermed er hun også immun mot klassisk ideologikritikk - det fins ingenting å "demaskere”, ingen naiv "miskjennelse” å sette fingeren på for den klarsynte opplysningsmann. Ideologien er innskrevet i kroppene våre; den befinner seg ikke lenger i kunnskapens domene, men i handlingens. I en slik situasjon er det håpløst å sette sin lit til "de sanne tankers iboende kraft". Somatiserte sosiale strukturer forsvinner ikke med et fingerknips - de kan bare utdrives gjennom langvarig, systematisk "dekoding" av individets habitus, en sosial mot-dressur analog til idrettsutøverens utrettelige tøying av sener og ledd. ${ }^{2}$

Situasjonistenes naive ideologiforståelse kommer til uttrykk bl.a. i deres analyser av byrommet. Temaet opptar dem voldsomt, særlig i SIs første fase, mens sosiologen Lefebvre ennå er tilknyttet bevegelsen. Et hovedpoeng er å avsløre byplanleggingens ideologiske karakter: Ifølge Attila Kotányi og Raoul Vaneigem er feltet identisk med "samfunnets sfære for publisitet og propaganda" (Kotányi og Vaneigem 25, min oversettelse). Byplanleggerne legger uhørte begrensninger på den menneskelig utfoldelse; “alt rom er okkupert av fienden”. Så langt, så godt - dette er tanker som i vår tid videreføres av bl.a. Adbusters og Reclaim the Street. Det går ikke riktig galt før forfatterne skal eksemplifisere. "Vi lever under et permanent portforbud. Ikke bare politiet - geometrien," skriver Kotanyi og Vaneigem, og lar oss forstå at også byens gatenett håndhever storkapitalens interesser. Trafikkflyten gjør det samme: "Å holde trafikken i gang er i sin essens å organisere universell isolasjon.” Man skulle tro at det var i alle samfunnsklassers interesse å unngå trafikkork i middagsrushet, men situasjonistene ser åpenbart annerledes på det. "Å holde trafikken i bevegelse," skriver de, "er det motsatte av å tillate folk å møtes; det suger opp all den energi som ellers kunne ha vært kanalisert inn i slike møter, eller andre former for deltagelse.” (Kotányi og Vaneigem: 25, min oversettelse).

Disse eksemplene er plukket relativt tilfeldig, men poenget skulle være tydelig nok: Situasjonistene lokaliserer den borgerlige ideologien "overalt", bare ikke der den virkelig har betydning - i det dypeste av de dominertes kropper. For situasjonistene

2 Begrepet er lånt fra Bourdieu. Se Pierre Bourdieu. Meditasjoner. Oslo: Pax Forlag, 1999: 179. 
er ideologikonsumentene rett og slett ofre for ekstern manipulasjon. Derfor trenger man heller ikke ta deres egen erfaring av verden på alvor; det avgjørende er til enhver tid å kunne identifisere statsapparatets propaganda, hva enten den er virksom i avisenes lederartikler eller i trafikklysene på Champs-Élysées. Situasjonistene ser altså bare maktens objektive strukturer, ikke de inkorporerte strukturene - og ei heller det prerefleksive samsvaret mellom indre og ytre, som langt på vei forklarer hvorfor den bestående orden har en så imponerende soliditet. Det mest påfallende ved et moderne byrom er nemlig ikke tettheten av lyskryss, forbudsskilt og veimerking, men som Bourdieu (igjen) påpeker - at denne trafikkens doxa i så høy grad blir respektert; at det ikke forekommer flere regelbrudd eller protesthandlinger: "Tenk bare på den ekstraordinære samstemmighet av tusener av disposisjoner - eller viljer - som ligger til grunn for fem minutters bevegelse av trafikken rundt Place de la Bastille eller Place de la Concorde ..." (Bourdieu, Masculine Domination 1, min oversettelse).

Situasjonistenes ideologikritikk blir altså både for vid og for smal; for krakilsk og for lite krakilsk - den tar ikke høyde for at de dominerte "samarbeider" med sine undertrykkere om opprettholdelsen av den symbolske orden. Likevel beskriver SI sin egen samfunnskritikk som en "totalkritikk". Premisset er at den eksisterende orden "glædeligt acceptere[r] delvise kritikker og endda benytte[r] disse som bevis på sin tolerance og frihed" (19-20). Problemet med et slikt utgangspunkt er ikke at det er "paranoid", men at det visker ut skillet mellom kapitalismekritikk og den filosofisk-sosiologiske kritikken av det som hos Lacan og Bourdieu kalles "den symbolske orden”. Satt på spissen: Også i et sosialistisk samfunn vil det eksistere trafikklys og - får vi håpe - en viss orden i trafikkbildet rundt middagstider. Den symbolske volden betinger ikke en kapitalistisk produksjonsmåte. Bolt var inne på dette i Den sidste avantgarde:

"Fremmedgørelsesforestillingen var baseret på et princip om, at man oprindeligt besad sig selv, at man ejede sit selv eller var herre over sig selv, og først derefter mistede sig selv i fremmedgørelsen. Først var der identitet, siden var der tab. [...] Situationisterne misforstod det fremmede ved menneskets tilstedeværelse på jorden og med andre, idet de knyttede fremmedgørelsen sammen med kritikken af den politiske økonomi." (Bolt, Den sidste avantgarde: 51).

Igjen: Det fins gode grunner til å betenke det eksistensielle faktum at "vi er utlevert til de andres blikk" (Gombrowicz), men dette har ingenting med kapitalismekritikk å gjøre. Hvis denne distinksjonen ikke trekkes skarpt nok, risikerer man å begå en ontologisk kategorifeil: Revolusjonen blir tilskrevet en egenskap som den logisk sett ikke kan inneha - den forventes å gjøre menneskene til "herrer over seg selv", selv om den strengt tatt bare ("bare") innebærer en redistribusjon av politisk og økonomisk makt. Derfor er det heller ikke usannsynlig at situasjonistene, dagen etter en tenkt revolusjon, ville ha fortsatt å propagere for "revolusjonen", ettersom de overalt møtte bekreftelser på at verden fremdeles var et nett av relasjoner (ikke en sum av frie og autonome individer). 
Da surrealistene brøt med det franske kommunistpartiet i 1935, proklamerte André Breton: “'Transformér verden', sa Marx; 'forvandle livet', sa Rimbaud. For oss utgjør disse to ordrer én.” (André Breton: "Discours au congrès des écrivains” (1935), sitert i Bolt 33, min oversettelse fra dansk). Men når Marx skriver "verden”, viser han til samfunnets produksjonsforhold; når Rimbaud skriver "livet", mener han - ja, livet i sin alminnelighet. Det går ikke ut på det samme. Slavoj Zizek har nylig advart mot generaliseringer som får kapitalismekritikken til å smelte sammen med en vag, uforpliktende kritikk av "den instrumentelle fornuft" og "den moderne teknologiske sivilisasjon”. Den kommunistiske bevegelsen må være "absolutt moderne”, skriver Zizek, paradoksalt nok med en referanse til nettopp Rimbauds Une Saison en Enfer ("il faut être absolument moderne"). (Zizek: 97).

Faren med "totalkritikken” er ikke først og fremst at den gjør sine talsmenn motløse, men at den gjør dem kyniske, idet de mister evnen til å skjelne mellom godt og ondt i politikken. Hvis vi virkelig lever i et "totalforvaltet samfunn" (Adorno) - har det da noen hensikt å holde seg med et sosialistisk arbeidsprogram? Vil ikke alle progressive initiativer uansett bli rekupert, kooptert og/eller repressivt tolerert? Et menneske som ikke ser forskjell, kan heller ikke gjøre forskjell. Altså får indifferensen fritt spillerom, liksom på den politiske høyrefløyen, hvor man for lengst har innsett at det er mulig å forføre massene med en ny-hobbesiansk likhetsidé - en påstand om at det som tross alt forener menneskeheten, er vår naturgitte egoisme, aggresjon og generelle nedrighet. Over hele Europa har høyrepopulistiske politikere fulgt denne oppskriften med suksess: For rullende kameraer innrømmer de gladelig at de smugler sprit, snyter på skatten og begjærer sin nestes hustru, uten at det gir seg utslag i annet enn økt oppslutning på partibarometrene. For er vi ikke alle "litt sånn”, når alt kommer til alt? Litt grådige, litt vulgære, litt rasistiske - innerst inne? Premisset er at den moralske, "politisk korrekte" posituren uansett bare skjuler en enda større umoral; derfor er en "ærlig drittsekk" langt å foretrekke framfor en venstreradikal filantrop.

Denne ombyttingen av sannhet og løgn, moral og umoral utgjør den ideologiske matrisen for all høyrepopulisme i vår tid. Minst av alt trenger vi, under slike forhold, analyser som feller dom over venstrefløyens politiske praksis ut fra en "alt eller ingenting”-logikk. At revolusjonen synes fjern, må aldri bli en unnskyldning for ikke å gjøre en forskjell til det bedre her og nå.

"Der er ikke nogen radikal andethed", beklager Mikkel Bolt i bokas siste kapittel (Bolt: 101). Bedre kan ikke problemet med Avantgardens selvmord oppsummeres: Som jeg har forsøkt å vise i denne artikkelen, er ideen om "radikal andethet" en idealistisk reminisens, analog til forestillinger om "motspråk" i poesien eller "indie" i rocken. Når "andetheden" dyrkes, forfaller den revolusjonære kritikken til livsstil: Det å være "revolusjonær” blir et spørsmål om å være ideologisk "ubesmittet". Bevegelsen lukker seg om seg selv; dens aktiviteter tappes for politisk bruksverdi.

Bolt har rett. Det finnes ingen utenfor-posisjoner. Dagens venstreradikale har 
ingen "andethed" å adressere sine bønner til. Skjønt dette er en omstendighet som burde feires, ikke begråtes: Et revolusjonært program med åndelig aroma er ikke et revolusjonært program, men et religionssubstitutt. Først når mennesket er bedratt for sin illusoriske lykke, kan det - som Marx påpekte - begynne å tenke, handle og gestalte sin egen virkelighet.

\section{LITTERATURLISTE}

Bolt, Mikkel. Den sidste avantgarde. Situationistisk Internationale hinsides kunst og politik. København:

Forlaget Politisk Revy, 2004.

Bourdieu, Pierre. Om fjernsynet. Oslo: Gyldendal, 1998.

Bourdieu, Pierre. Meditasjoner. Oslo: Pax Forlag, 1999.

Bourdieu, Pierre. Konstens regler. Det litterära fältets uppkomst och struktur. Stockholm/Stehag: Brutus

Östlings Bokförlag Symposion, 2000.

Bourdieu, Pierre. Masculine Domination. Cambridge: Polity Press, 2001.

Debord, Guy. Skuespillsamfunnet. Oslo/Bergen: News from NowHere/Gasspedal, 2009.

Eagleton, Terry. Walter Benjamin or Towards a Revolutionary Criticism. London/New York: Verso, 2009. Hegel, Georg Wilhelm Friedrich. Werke. Band 1. Frankfurt am Main: Suhrkamp, 1979.

Kotányi, Attila og Raoul Vaneigem. "Unitary Urbanism" Leaving the 20th Century. The Incomplete Work of the Situationist International. London: Rebel Press, 1998 (opr. trykt i Situationiste Internationnale nr. 6/1961).

Schelling, F.W.J. Den tyske idealismens eldste systemprogram [1796/97], oversatt av Arnfinn Bø-Rygg i Kjersti Bale og Arnfinn Bø-Rygg (red.): Estetisk teori. En antologi. Oslo: Universitetsforlaget, 2008. Schelling, F.W.J. System des transcendentalen Idealismus [1800], sitert i Peter Bürger: Zur Kritik der idealistischen Ästhetik. Frankfurt am Main: Suhrkamp, 1983.

Zizek, Slavoj. First As Tragedy, Then As Farce. London/New York: Verso, 2009.

Bendik Wold (f. 1979) er forlagssjef i Flamme Forlag. Han er tidligere bokredaktør i de norske avisene Morgenbladet og Klassekampen, og har bl.a. utgitt Tredje venstre. For en radikal individualisme (2004, sammen med Magnus E. Marsdal). 